\title{
The Technopolitics of Infrastructure Breakdowns: A Historical Overview of Dumsor
}

\author{
Claudia Serwah Prempeh'1 \\ 1 Bayreuth International Graduate School of African Studies (BIGSAS), University of Bayreuth, Germany.
}

\begin{abstract}
In sub-Saharan Africa, Ghana is considered a beacon of success because of its high electricity access rate: 84.3 per cent as at 2018. Despite this success, the sector is entangled in a crisis. Crisis as used here refers to the crisis of electricity supply where supply deficits results in prolonged periods of blackouts and load rationing. Between 2012 and 2016, blackouts christened dumsor (Twi word for off/on) became a regular experience in Ghana with more blackouts than electricity supplied: 24 hours lights out, 12 hours light supplied. Using a historical narrative, this article provides a summarized account of how dumsor unravelledthe momentous cascading socio-economic interruption dumsor caused, the dramatic user responses it evoked and the ways in which it became the subject of intense political debate. Primary data was gathered from ethnographic fieldwork and secondary data from online and archival sources. This narration reveals the generative potential of uncertain infrastructure and its ability to foreground the "under the radar" interdependences between infrastructure and political power. It details how an "imperfect" electric infrastructure produced new user subjectivities, challenged the conduct of electricity governance and revealed electricity provisioning to be a starkly contested technopolitical process.
\end{abstract}

Correspondence

Claudia Serwah Prempeh Email: claudia_prempeh@yahoo. co.uk

Publication History Received 20th September 2020, Accepted 29th October 2020, Published online 6th November 2020.

Keywords: Technopolitics, Blackouts, Dumsor, Infrastructure

\section{INTRODUCTION}

"The Dumsorification of Ghana has had a Dumsorforic effect on the country. We now await Dumsorly for the end of Dumsor."

In 2010, Ghana was considered one of the fastest growing economies in the world. After conducting six democratic elections and smooth transfers of political power between 1992 and 2012. It had experienced more than a decade of sustained economic growth which was contributing to poverty reduction, a notable annual economic growth rate of about 5 percent over the past five years. The economic prospects was indeed projected to be very bright. Ghana's recalculation of its GDP in 2010 also led to its overnight graduation from a poor country to a Low-Middle Income Country (LMIC). Plans for industrialization and massive expansion of the economy became topical following the official production and exportation of oil in 2010. The Ghana Shared Growth and Development Agenda (GSGDA), which was the medium-term development framework of Ghana outlined plans to facilitate this and ensure Ghana's progressive socio-economic development. Especially for the energy sector, the hopes were brighter. The Government launched a policy which aimed at increasing installed capacity to $5000 \mathrm{MW}$ and to become a major exporter of electricity by $2015 .^{2}$ However, dumsor hit.

\footnotetext{
Abebrese, Ama K (@Ama_K_Abebrese). "The Dumsorification of \#Ghana Has Had a Dumsorforic Effect on the Country. We Now Await Dumsorly for the End of \#Dumsor," Twitter, November 25, 2015, 3:23 am https://twitter.com/Ama_K_Abebrese/status/669521731028164608

2 Ministry of Energy, “National Energy Policy.” 2010, http://www.purc.com.gh/purc/sites/default/files/ENERGYPOLICY.pdf
} 


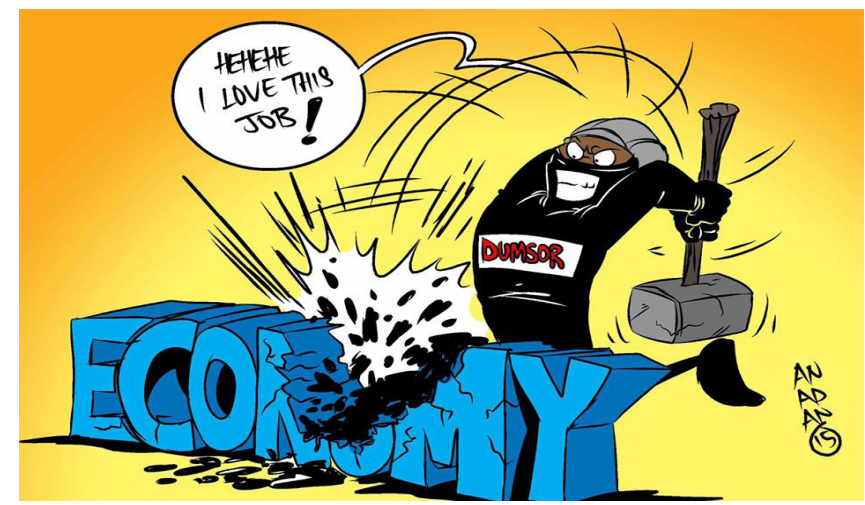

Fig 1. Dumsor: "Hehehe, I love this job!" Credit: Anadan 2015

The Dumsorification of Ghana was the gradual process through which Accra succumbed to a vortex of cascading collapse: the flickering disconnections, connections and partial connection blacked out the economy, reconfigured everyday life and was described as crushing (as seen in Fig 1). Dumsor is a colloquial Ghanaian Twi word used to describe power outage; dum translates off and sor translates on. The technical term for dumsor is load shedding, it means rationing power provision in order to lower the demand of overwhelmed power production facilities. As one poster remarked: "dumsor is village explanation of power crisis and load shedding is the engineering cocastic explanation to dazzle the village folks"3 Dumsor trended so extensively that it made its way onto Wikipedia, urban dictionary and Macmillan open online dictionary.

Blackouts are not uncommon practice in Ghana and similar crisis were experienced in 1984, 1998, 2002 and between 2006 and 2007. However, the intensity and the irregularity of dumsor left much to be desired. Thus, dumsor became the popular Ghanaian term for power cuts which the political elite and bureaucrats described as a "power crisis". Between 2012 and 2016, dumsor became a regular experience in Ghana with more blackouts than electricity: 24 hours power outage with 12 hours power supplied each day. Initially promoted by the opposition political parties as a satirical term, dumsor became a strategic term used by majority of citizens to express despondency over the erratic electricity supply. When dumsor started, state agencies maintained that there was no electricity crisis. President Mahama, Ministers and other political appointees buttressed this official position with contradictory speeches and promises. The management of the crisis by power sector duty bearers was in itself a crisis as they did not seem to have control over causative factors namely fuel insecurity, unplanned plant break downs and lack of generation reserve.

Current studies on infrastructure breakdowns do not focus adequately on the politics of state and user responses. To fill this gap, this article analyses the technopolitical style of managing the grid in crisis mode and the consequent citizen and partisan political responses it generated to establish the co-constitutive relationality between politicians, electric infrastructure, political ideology and technocracy. The author uses dumsor as a heuristic device to show the often hidden sociotechnical relations consitutuive and performative of electricity govrnance in Ghana. In Accra, the trending of dumsor on radio and social media opened new public spaces for political engagement. Dumsor reconfigured political subjectivities ${ }^{4}$ and shows that infrastructure governance is not a technocratically neutral activity. Accordingly, this article seeks to expand the interactional mechanisms between politics and infrstrucure governance and contribute to the growing but limited literature on technopolitics and infrastrure breakdowns in developing economies.

\section{METHODOLOGY}

This article is based on ethnographic fieldwork carried out in Accra between 2015 and 2017 and secondary data obtained from online and archival sources. About 50 semi-structured interviews were conducted with a wide range of actors in Ghana's electricity governance space: national policymakers, Civil-Society Organisations, state and private utility-company staff, industry representatives, private business owners and others. The Author also spent time observing the work of policy makers and utility organisations. The Author engages the concept of technopolitics to historically narrate the socio-political spectacle dumsor generated and the "crisis effects" thereof noting (i) government's strategies to manage public confidence and "tame" the grid, which during dumsor was widely represented as ungovernable and (ii) user responses to infrastructure breakdown and how opposition parties strategically mobilized the voter representation of dumsor to enact their political goals as forms of technopolitics.

\footnotetext{
Nana Sarpong, Agyeman, “@IngSarpong: Dumsor Is Village Explanation of Power Crisis \& Load Shedding Is the Engineering Cocastic Explanation to Dazzle the Village Folks.” https://twitter.com/IngSarpong/status/667244368177332224

4 Penelope Harvey, Casper Bruun Jensen, and Atsuro Morita. "Introduction: Infrastructural Complications." In Infrastructures and Social Complexity: A Companion, edited by Penelope Harvey, Casper B. Jensen, and Atsurō Morita, 1-22. Culture, economy and the social. (London, New York: Routledge, Taylor \& Francis Group, 2017).

5 Daromir, Rudnyckyj, "Crisis Effects.” Cult. Anthropol. 33 no 4 (2018): 547-57. https://doi.org/10.14506/ca33.4.04
} 
The Author draws on dumsor and the socio-political spectacle it generated to explore what such responses suggest about infrastructure politics in the developing context where infrastructure breakdown is normalised. ${ }^{6}$

\section{The Technopolitics of Infrastructure Breakdowns}

The co-constitutive relation between electricity and development is well established in literature. Starting with White's assertion that "when energy for culture-living and culture building is augmented in quantity, is expended more efficiently, and culture advances", to Nye's contextualist assertion that more energy does not correlate to more development, instead as more people adopt electricity and see its benefits, they become locked into the grid because of the ease and convenience that it brings to their daily practices. ${ }^{8}$ Since its discovery, electricity has successfully positioned itself as a prime mover in social change so much so that it was revered a goddess ${ }^{9}$ and an energy that sustains a magic culture ${ }^{10}$ Magic and goddess because if users do not understand the inner workings of any technology, it looks like magic. ${ }^{11}$

Due to the heavy state involvement in management of electricity, it is impossible to separate its technical and political dimensions. In the developing economies, governments informed by a developmentalist ideology placed electricity provisioning at the heart of nation state formation with electricity emerging as a means to materialise their political ideology, modernist visions of progress and "enchant" and dazzle voters. ${ }^{12}$ Thus, a social contract emerged where governments see electricity provision as a way to "serve the public good" 13 and citizens in turn, see its provision as a state responsibility and their access to reliable electricity as a citizenship right. Its management, then is perceived as a government responsibility and the consequence of their breakdown evokes dire political controversies because users do not experience electricity disruptions as mere technical events, but also as governmental incompetency.

In STS and anthropology, the concept of technopolitics can be traced to Winner's theory of technological politics which states that technology is political by default because the choice of which technology to build is inherently a political choice and also because of the contestation and negotiations that characterise the decision making process among interdependent actors in system building. ${ }^{14} \mathrm{Hecht}$ defined technopolitics as "the strategic practice of designing or using technology to constitute, embody, or enact political goals". ${ }^{15} \mathrm{Hecht's}$ definition related to two forms of technology: hardware and institutional arrangements (i.e. regulations, policy instruments etc.) ${ }^{16}$ Subsequently, authors have appropriated the concept to represent the practice of designing material artefacts to foster political ends, (ii) practice of designing the social, i.e. laws, policy instruments and humans to foster politics in technological spaces (iii) citizens using technology as political terrain to negotiate their socioeconomic needs. ${ }^{17}$

The technopolitical argument boils down to how actors with different logics and strategies recursively exercise choice to constitute the shape and ordering of infrastructure and how the shape and ordering of infrastructure also informs political choices. While these studies concentrate on infrastructure design or infrastructure in the making or how particular system configurations enact specific socio-political forms and order, it does not discuss infrastructure breakdowns as a terrain for the enactment of macro and micro technopolitics. The Author uses technopolitics to characterise "hybrids of technical and political practices" and the consequent contingent and material forms of "power

\footnotetext{
6 Stephen Graham and Nigel Thrift. “Out of Order.” Theory, Culture \& Society 24 no 3 (2007): 1-25. https://doi.org/10.1177/0263276407075954; Stephen Graham, Stephen and Simon Marvin. Splintering Urbanism: Networked Infrastructures, Technological Mobilities and the Urban Condition. (London, New York: Routledge, 2001); Stephen Graham, "When Infrastructures Fail." In Disrupted Cities: When Infrastructure fails, edited by Stephen Graham. 1st ed (New York, NY: Routledge) $1-26$.

Leslie A White, "Energy and the Evolution of Culture," American Anthropologist, New Series 45, no. 3 (1943): 335-56. Accessed October $22,2015$.

David E Nye, Consuming Power: A Social History of American Energies, (Cambridge Mass: MIT Press, 1998).

Merritt Roe Smith, “Technological Determinism in American Culture?” In Does Technology Drive History? The Dilemma of Technological Determinism, ed. Merritt R. Smith and Leo Marx, (Cambridge, Mass: MIT Press, 1994), 3-34.

10 Stephanie Rupp, “Considering Energy E = Mc2 = (Magic Culture)2," In Cultures of Energy: Power, Practices, Technologies, ed. Sarah Strauss, Stephanie Rupp and Thomas F. Love,(Walnut Creek, CA: Left Coast Press, 2013) 79-98.

11 Geoffrey C. Bowker and Susan Leigh Star, Sorting Things Out: Classification and Its Consequences, Inside technology, (Cambridge, Mass.,London: MIT Press, 1999).

12 Penny Harvey and Hannah Knox, “The Enchantments of Infrastructure,” Mobilities 7, no. 4 (2012): 521-36.

13 Marco Di Nunzio,"Anthropology of Infrastructure,” Governing Infrastructure Interfaces Research Note, no.01 (2018):1.

14 Langdon Winner, “Do Artifacts Have Politics?” Daedalus 109, no. 1 (1980): 121-36.

${ }_{15}$ Gabrielle Hecht, "Technology, Politics, and National Identity in France." In Technologies of Power:Essays in Honor of Thomas Parke Hughes and Agatha Chipley Hughes, eds Michael T. Allen and Gabrielle Hecht, (Cambridge, Mass: MIT Press, 2001), 256.

16 Gabrielle Hecht, "Technology, Politics, and National Identity in France.” In Technologies of Power:Essays in Honor of Thomas Parke Hughes and Agatha Chipley Hughes, eds Michael T. Allen and Gabrielle Hecht, (Cambridge, Mass: MIT Press, 2001), 253-94..

17 Anand, "Pressure: The Politechnics of Water Supply in Mumbai," (2011): 542-64; Anand, "Municipal Disconnect: On Abject Water and Its Urban Infrastructures," (2012): 487-509; Anand, "Leaky States: Water Audits, Ignorance, and the Politics of Infrastructure," (2015): 305-30; Edwards and Hecht, "History and the Technopolitics of Identity: The Case of Apartheid South Africa." (2010): 619-39; Hecht, The Radiance of France: Nuclear Power and National Identity after World War II, 1998; Hecht, "Technology, Politics, and National Identity in France.” In Technologies of Power: Essays in Honor of Thomas Parke Hughes and Agatha Chipley Hughes, 2001; Hecht, "Introduction." In The Radiance of France: Nuclear Power and National Identity after World War II. Edited by Gabrielle Hecht, 2009:1-20. Mitchell, Rule of Experts: Egypt, Techno-Politics, Modernity, 2002; Mitchell, "Carbon Democracy,” (2009): 399-432; von Schnitzler, "Citizenship Prepaid: Water, Calculability, and Techno-Politics in South Africa*." (2008): 899-917; von Schnitzler "Traveling Technologies: Infrastructure, Ethical Regimes, and the Materiality of Politics in South Africa.” (2013): 670-93; von Schnitzler, Democracy's Infrastructure: Techno-Politics and Protest after Apartheid, 2016.
} 
and agency" that emerges in response to infrastructure breakdowns. ${ }^{18}$ This notion of technopolitics highlights the nature of emergent co-constitutive macro-micro material politics enacted when infrastructure fails to realize its technopolitical promises. The Author uses it to track the co-emergent state and citizen action, how political power was exercised in response to citizen's request for technical solutions, the political aims of such political interventions, and consequences thereof.

\section{FINDINGS AND DISCUSSION}

\section{4: Dumsor turned dum koraa}

Although the term dumsor gained popularity in 2012, as early as 2010, the term dumsor was being used. The dumsorification of Ghana did not happen overnight. As early as 2009, the Energy Commission, ${ }^{19}$ the state technical regulator, projected that Ghana will experience electricity supply shortfalls if government did not secure fuel and expand generation capacity. Going into 2012, based on intelligence gathering, it predicted that political volatility in Nigeria was going to affect natural gas supply from WAPCo. ${ }^{20}$ Unfortunately in August 2012, the Energy Commission's forecast materialised: a pirate attack on the West African Gas Pipeline (WAGP) resulted in its complete shutdown. The grid lost 200MW resulting from the shutdown of the Sunon-Asogli plant ${ }^{21}$ and exacerbated dumsor. Even before the pirate attack, outages were worsening because of low gas supply. ${ }^{22}$

Despite public outcry and apprehensions, government response was slow and it did not admit there was a power crisis until late 2012 when it initiated moves to procure emergency power and started load rationing. In the face of growing public discontent, government had to be seen to be doing something. It resorted to arbitrary symbolic acts and promises. President Mahama who was Head of State at the time, variously through public speeches ${ }^{23}$ gave timelines and promised to end dumsor ${ }^{24}$ and made ending dumsor a major campaign in the 2012 presidential elections. As early as January 2013, voters realised they had been misled; dumsor had not just resumed, but had worsened too. President Mahama received a little respite in July 2013 when the WAPCo resumed operation, almost a year after breakdown and the 200MW Sunnon Asogli ${ }^{25}$ started operation.

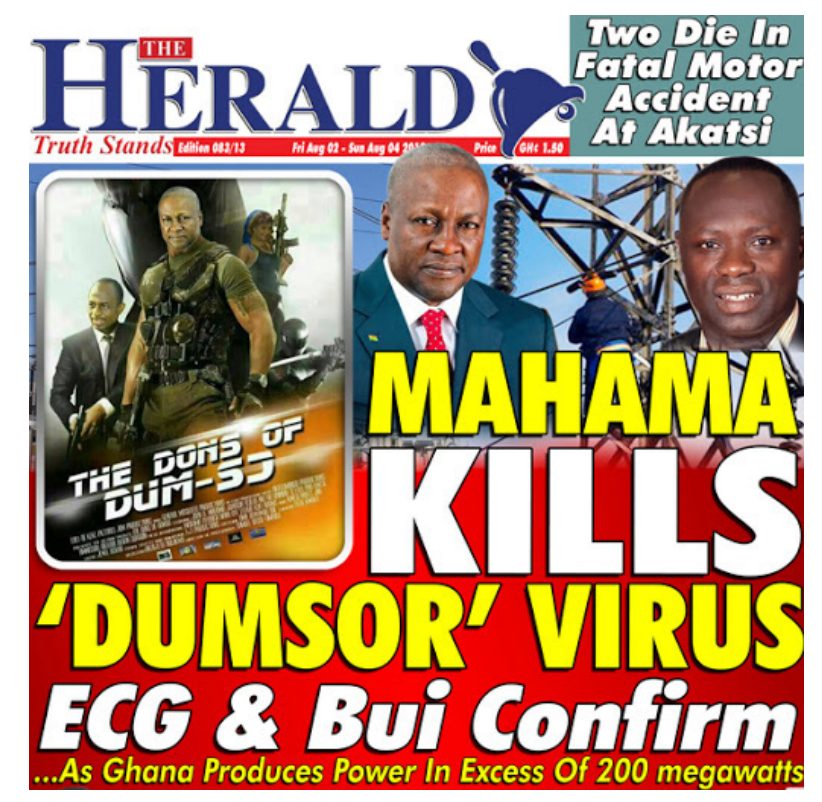

Fig 2: “John Mahama Kills 'Dumsor' Virus. Credit: Dogbey, 2013

As seen in Figure 2, some commentators reported that President Mahama had killed the dumsor virus - "it appears President President Mahama, who publicly declared he had sleepless nights over the power crisis and was even

\footnotetext{
18 Paul N Edwards and Gabrielle Hecht, "History and the Technopolitics of Identity: The Case of Apartheid South Africa," Journal of Southern African Studies 36, no. 3 (2010): 619-39, 256

19 Energy Commission, “2010 Energy (Supply and Demand) Outlook for Ghana,” Energy Commission, Accra, 2010.

20 WAPCo stands for West African Gas Pipeline Company. It operates the West African Gas Pipeline and has been supplying the Volta River Authority with gas from NGas Nigeria since April 2009.

21 The Sunon-Asogli-plant is a wholly natural gas fuelled.

22 Gas supply was half that of 2011 (Energy commission 2013, 1-2).

23 President Mahama gave the public speeches in September, October and November 2012, February 2013 and April 2013,: Solving dumsor was not a priority for President Mahama - Bawumia, Accessed July 4, 2016, https://www.myjoyonline.com/news/solving-dumsor-was-not-a-priority-for-President Mahama-bawumia/.

24 Sydney Casely-Hayford, "Ntro Twa-Preneur," Updated July 7, 2015 https://www.peacefmonline.com/pages/comment/features/201512/264170.php; S Quashie, "This Timeline Dates Far Back as 2012 and Ends with the Latest Comment on the Power Crisis by John Mahama," May 5, 2015 , Accessed July 4, 2015.

25 The 200MW Sunnon Asogli power plant relies only on gas from WAPCO for operations.
} 
cartooned [...] in a picture captioned "The Dons of Dumsor", might be sleeping comfortably now". ${ }^{26}$

In 2013, dumsor worsened and public discontent heighten. As Ghanaians waited dumsorly for the end of dumsor, the dumsorification intensified in 2014. Dumsorly, as used here refers to the uncertain on and off disco like hope users received from the President's promises to end dumsor. For Carlisle et. al, trust plays a crucial role in managing energy crisis. They note that during crisis, when people demand answers from stakeholders at the helm of crisis resolution and they are met with untruths, it breaches public trust and this affects how they receive future information. ${ }^{27}$ Citizens were no longer persuaded by promises. Their experience of unfulfilled past promises had taught them not to trust President Mahama and official statements from state utilities: credibility was lost, because if "you trust the messenger, you believe the message." On January 12014 , the grid recorded its highest ever peak load demand signalling increased electricity demand. ${ }^{28}$ Supply could not match demand and so an equivalent of 450-620 MW load was shed ${ }^{29}$ and partly accounted for a decrease Ghana's real GDP. ${ }^{30}$

Amidst load shedding and the rising public outrage, the PURC announced tariff increases in October 2014. This attracted further public outcry. In response to the tariff increase, AFAG issued a press release condemning government. In the release, it noted that the "dumsor has become dumkoraa", signalling the further dumsorification of an already dumsorified Ghana. ${ }^{31}$ Dumkoraa is Twi language and translated on and off has deteriorated into only off. A 2014 cost of unserved power study on micro and small-scale businesses or enterprises that found that their annual sales had decreased by about 37 to 48 per cent; Ghana was losing about US\$2.2 million daily, US\$57 million every month and $\$ 686.4$ million annually. ${ }^{32}$ Also, between December 2014 and end of first quarter 2015, about 1,000 industrial workers had been laid off. ${ }^{33}$

In November 2014, as a sign of having a "more focused handle on the challenges facing the power sector", President Mahama created the Ministry of Power out of the Ministry of Energy, appointed Kwabena Donkor as Minister and tasked him "to end dumsor quickly." ${ }^{34}$ President Mahama's Industry observers were unanimous that Ghana did not need a new ministry (a new cost centre), it just needed funds to meet fuel supply challenges. Before his appointment, Donkor was a staunch critic of the Government's "mis-management" of dumsor. In one of those critics, he described government's continued reliance on Nigeria for Gas as "mentally retarding" and "intellectually lazy." ${ }^{35}$ Upon taking office, an over enthusiastic Donkor promised to resign if he did not resolve dumsor by end of 2015. Observers saw through and commented extensively on his performative declaration. Online, citizens started a countdown to the end of dumsor and countdown to Donkor's resignation.

The precarious everyday consumer experiences with state-run monopoly electricity service is connected to the state primarily via state utilities. As von Schnitzler notes, these relations are moderated by "technical administrative devices like meters, cables, transformers and utilities' tremendous "discretionary" power which often results in actions ranging anywhere in between care and abject neglect. ${ }^{36}$ Consumers experienced dumsor as governmental neglect: through Electricty Company of Ghana's (ECG $)^{37}$ poor customer service, non adherence to dumsor league table ${ }^{38}$ and not restoring power on schedule. ECGs discretionary power to curtail power was cast as state tyranny and as a government not caring about how citizens lived. Citizens acted out these feelings of neglect by mocking ECG as standing for Either Candle or Generator, Enemies of Comfortable Ghana and Enimguase Company of Ghana. Enimguase means disgrace in

\footnotetext{
26 Alfred K Dogbey, “End of 'Dum so Dumso': Mahama Sleeping Comfortably Now.” August 5, 2013. Accessed March 25, 2020, https://www.ghanaweb.com/ GhanaHomePage/NewsArchive/End-of-Dum-so-Dumso-Mahamasleeping-comfortably-now-281485

27 Juliet E Carlisle, Jessica T. Feezell, Kristy E. H. Michaud, and Eric R. A. N. Smith, The Politics of Energy Crises, (New York, NY: Oxford University Press, 2017), 69.

28 Volta River Authority, Fifty Third Annual Report \& Accounts 2014. 11. The load demand recorded was 1,970.9MW signalling increased electricity demand.

29 Although installed capacity was 2,831 MW, only 2552MW was dependable; of this only 1,482MW was available (Energy Commission 2015). An equivalent of 450-620 MW load was shed and partly accounted for a decrease in impacted Ghana's real Gross Domestic Product (GDP) growth: decreased to 4.2 per cent from the 7.1 per cent (2013) and 8.8 per cent in 2012 (Energy commission 2015, i-2, VRA 2014).

30 GDP decreased to 4.2 per cent from the 7.1 per cent (2013) and 8.8 per cent in 2012 (Energy commission 2015, i-2, VRA 2014).

31 AFAG described itself as a pressure and advocacy group: AFAG, “Another Utility Increase; Unbearable Hardship-Time to Strike., October, 2014.” News release.

32 Charles Ackah, "Electricity Insecurity and Its Impact on Micro and Small Businesses. Report Presentation Given to Economy of Ghana Network of the Institute of Statistical, Social, and Economic Research, May 14, 2015,” Updated May 14, 2015; Raymond Acquah, “\$2.2 Million Lost Daily to 'Dumsor'ISSER." Updated May 14, 2015”, http://citifmonline.com/2015/05/2-2-million-lost-daily-to-dumsor-isser/.

33 Energy Commission, "2015 Energy (Supply and Demand) Outlook for Ghana," Energy Commission, Accra, 2015.

34 Flagstaff House Communications Bureau, “Mahama Tasks New Power Minister to End 'Dumsor' Quickly,”December 20, 2014, Accessed September 23, 2020, https://www.ghanaweb.com/GhanaHomePage/NewsArchive/Mahama-tasks-new-Power-Minister-to-end-dumsor-quickly-339869

35 Nathan Gadugah, “Ghana's Power Crisis; a Slippery Slope to Eternal Darkness.”https://www.todaygh.com/ghanas-power-crisis-slippery-slope-eternaldarkness/https://www.ghanaweb.com/GhanaHomePage/NewsArchive/Power-crisis-Ghanaians-to-suffer-fresh-bout-of-darkness-303371, Accessed March 7, 2020. Before his appointment, Kwabena Donkor was the Chairman of Parliament's Mines and Energy Committee, a former Energy Minister, a leading member of the ruling NDC.

36 Antina von Schnitzler, Democracy's Infrastructure: Techno-Politics and Protest after Apartheid, Princeton Studies in Culture and Technology, (Princeton: Princeton University Press, 2016), 4.

37 Electricity Company of Ghana Limited is the State owned distributor of electricity.

38 The load shedding schedule was tagged as dumsor League Table: Kojo, Emmanuel. "ECG Releases 'Dumsor' League Table.” February 6, 2015a. Accessed September 23, 2020. https://www.pulse.com.gh/news/energy-crisis-ecg-releases-dumsor-league-table/b4w7g32
} 
the Twi language. Viewed as the disgrace of the nation and the thief of comfort, ECG became the target of physical and verbal assaults.

In December 2014, after two years of many failed promises, President Mahama promised not to make promises again. ${ }^{39}$ Figure 3 shows the Chronology of President Mahama's Promises to end Dumsor. However, later that month he came out to say he will "banish dumsor forever" and continued to say that " 2015 will be one in which we will banish darkness from our land and put an end to dumsor forever". ${ }^{40} \mathrm{After}$ intense criticism from the outraged public, President Mahama clarified that his promise to banish dumsor was "a prayer request he made to God on behalf of all Ghanaians and was confident that God had listened to the prayer"41 State officials were chiding religious verses like "dumsor will be like the Egyptians; we shall see them no more". ${ }^{42}$ It is worth noting that the President's promises were based on technocratic advice; it was later reported that the Chief Director of the Energy Ministry suggested that the technocrats should stop "deceiving the politicians with all kinds of timelines that are not realistic". ${ }^{33}$ At this point, citizens just wanted action: as a customer advocate note "the energy problem has gone beyond discussion. I think we just need government to act that fast." ${ }^{44}$

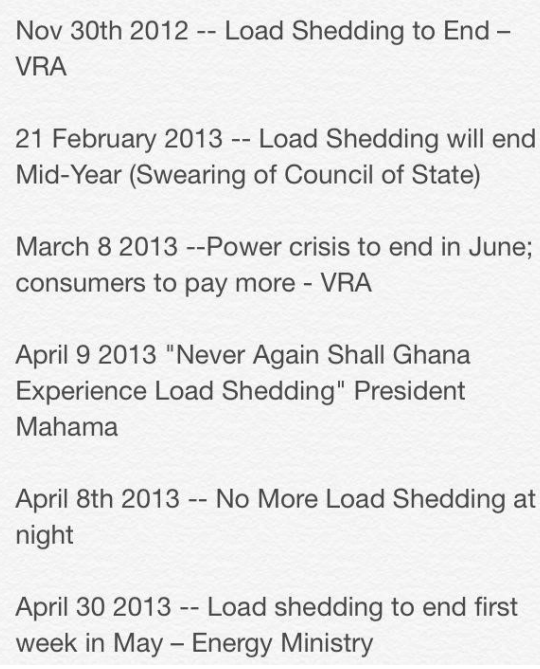

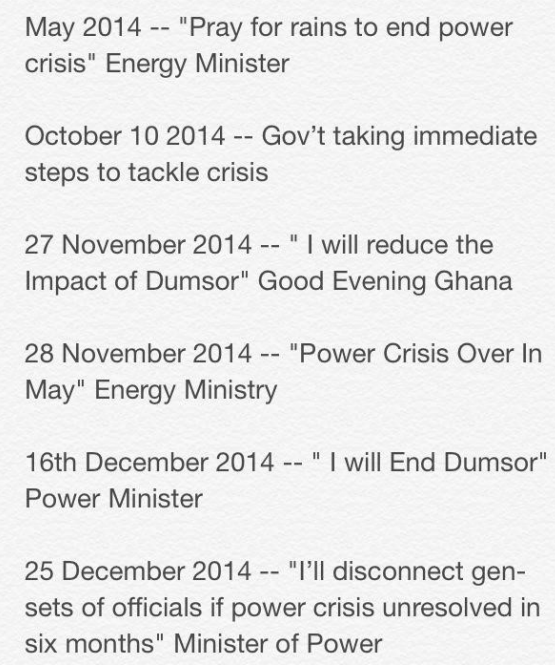

Fig 3: Chronology of President Mahama's Promises to end Dumsor. Credit: Nene, $2015^{45}$

\section{Media Dumsorification}

Dumsor dominated daily in print media as well as television and radio call-in opinion shows. Building on Thomas Brikland's concept of focusing events, ${ }^{46}$ Carlisle et. al, conceive energy crisis as focusing events because it has a high propensity to influence and generate public opinion which attract media attention and drives political response. ${ }^{47}$ As a focusing event, public anger reflected in public opinion drew media attention to dumsor and moved it to the top of the national news and political agenda because the conditions it created were untenable. Between 1989 and 1990, Ghana became one the first countries in Sub-Saharan Africa to introduce internet services. ${ }^{48}$ Since then, its usage has expanded and despite its poor infrastructure, limited access and its association with cyber-crime and economic opportunism in Ghana, internet use is a vibrant and innovative means for information-seeking, communication, entertainment, political mobilization. ${ }^{49}$ In Ghana, the dominant internet social media platforms are Facebook, WhatsApp, Instagram and twitter.

\footnotetext{
39 For a chronology of promises: https://www.myjoyonline.com/news/solving-dumsor-was-not-a-priority-for-President Mahama-bawumia/. Accessed March 5, 2020; William Yaw Owusu, "Mahama Pledges Not to Make Promises to Ghanaians Again," December 3, 2014, Accessed March 5, 2020, https://newsghana.com.gh/mahama-pledges-not-to-make-promises-to-ghanaians-again/.

40 Efua Idan Osam, “I Will 'Banish Dumsor Forever' - Mahama,” July 7, 2015a, Accessed September 23, 2020, http://citifmonline.com/2015/01/will-banish-dumsor-forever-mahama/.

41 Samuel K Obour, "My Banish Dumsor" Comment Was Only a Prayer Request - President Mahama," January 7, 2015, Accessed September 23, 2020, https:// www.graphic.com.gh/news/politics/my-banish-dumsor-comment-was-only-a-prayer-request-president-mahama.html.

42 Peacefmonline.com.,"Dumsor Will Be Like the Egyptians; We Shall See Them No More Minister," February 5, 2015, Accessed March 17, 2020, https://www.peacefmonline.com/pages/local/news/201502/231358.php.

43 Efua Idan Osam, "Stop Embarrassing Yourself - Cudjoe to Power Minister," May 9, 2015b, Accessed March 23, 2020, http://citifmonline.com/2015/05/stop-embarrassing-yourself-cudjoe-to-power-minister/

44 Efua Idan Osam, Stop Embarrassing Yourself - Cudjoe to Power Minister, May 9, 2015b.

45 Nene, O. Nene (@NeneMAGORTEY). “Chronology of Mahama’s Promises to End Dumsor," Twitter May16, 2015. https://twitter.com/NeneMAGORTEY/status/599618716096143360.

46 Thomas A Birkland, After Disaster: Agenda Setting, Public Policy, and Focusing Events, American governance and public policy, (Washington, DC: Georgetown University Press, 1997).

47 Carlisle et al.,The Politics of Energy Crises, (New York, NY: Oxford University Press, 2017).

48 Araba, Sey, "New Media Practices in Ghana," International Journal of Communication 5 (2011), 381.

49 Sey, "New Media Practices in Ghana", 2011.
} 
Mainstream traditional media have recognised the growing influence of social media and so all media outfits now have social media pages that posts digital copies of stories carried in print or on television for comments and sharing. Some mainstream media pick their stories from social media.

Altogether, the conjunction of internet, liberal radio, television and mobile phone environments has produced a public sphere, one that Tettey describes as "one of the most vibrant" in Ghana..$^{50}$ Tettey also notes that through the combined instantaneity of phone-in contributions or text messaging on these platforms with "timely" feedback from duty bearers who are called in to respond, enables ordinary citizens get to directly engage in political and socioeconomic discourse. ${ }^{51}$ This expansion of the public sphere has altered the demography of contributors to include the poor, minority and marginalised who otherwise will not be able to access mainstream media or duty bearers. ${ }^{52}$ As observed by Hasty; waking up in your house any morning in the bustling Ghanaian capital of Accra, one is drawn into local news bursting from radio and TV stations discussing new and trending news of the day - whether you walk, take a taxi, or ride the bus to work, someone around you is reading, listening, or discussing the news, usually adding context and commentary and inviting your own participation. Wherever one finds himself, be it with friends, colleagues, and customers, throughout the day there is an intermittent yet ongoing commentary on local, national, and global events ${ }^{33}$

Although a crippling phenomenon, the dumsorification of the media landscape ignited the airwaves and it exploded with ferocious anger and euphoric enthusiasm. Any frequent visitor to Accra will be conversant with the ferocious political discussions that take place in the Ghanaian media. There is always one scandal or the other sending shocking waves through the country. Dumsor was no different, except this "scandal" had been lingering for almost three years and nothing seemed to be working. Issues trend and have shorter attention but dumsor was a large scale failure with cross-cutting affects across the entire economy. In typical style, the airwaves were electrified with banter and politically charged interviews over "official information, unofficial leaks, scholarly analysis, popular commentary, rumours, and jokes" ${ }^{54}$ Below are a number of newspaper headlines that reflected the mix of growing public discontent:

"Nationwide power crisis worsens" "Power crisis to sink GDP to 2 percent - ISSER" 55

\author{
"AGI to lay off workers over power crisis" 56 \\ "Dumsor' Causes 13,000 Job Cuts in Four Months"57 \\ "Dumsor crisis: Over 12,000 workers lose jobs in first quarter"58 \\ "Government needs \$4bn to solve energy crisis" 59
}

\begin{abstract}
Dumsor reportage were a mix of "fact", emotionally charged personal opinion and speculation and often, the lines between personal attacks and constructive criticism were blurred. ${ }^{60}$ The impact of dumsor was critical and direct; its intense disruptions marred the social experience of users, it was visible to all and so the media did not need convincing that dumsor was a problem. The media were not amplifying the agenda for a problem unknown to them, they lived in dumsor and they were consumers and victims of dumsor. It influenced their mood and sentiments and so dumsor quickly rose to the top of the news agenda and stayed there for more than three years. Citizens used social media and call-in shows as the "public sphere" to publicize their private apprehensions, businesses and deteriorating socio-economic consequences of dumsor, vent their disappointment with government and mostly just demanding or appealing to ECG to bring back their light. The hashtag \#bringbackourlight coined to rhythm with the \#bringbackourgirls ${ }^{61}$ and this trended extensively on social media. Citizens critiqued sector issues through "politainment" - circulation of political satire and embarrassing

\footnotetext{
50 Wisdom J Tettey, "Mobile Telephony and Democracy in Ghana: Interrogating the Changing Ecology of Citizen Engagement and Political Communication," Telecommunications Policy 41, 7-8 (2017): 685-94, https://doi.org/10.1016/j.telpol.2017.05.012.

51 Tettey, Mobile Telephony and Democracy in Ghana, 2017.

52 Ernestina Edem Selormey, "Citizen Voice and Bureaucratic Responsiveness FM Radio Phone-Ins and the Delivery of Municipal and Local Government Services in Accra, Ghana," Doctor of Philosophy, University Of Sussex, 2013; Tettey, Mobile Telephony and Democracy in Ghana, 2017.

53 Jennifer Hasty, The Press and Political Culture in Ghana, (Bloomington: Indiana University Press, 2005$), 1$.

54 Hasty, The Press and Political Culture, 2.

55 Myjoyonline, "Nationwide Power Crisis Worsens," July 15, 2015, Accessed June 4, 2016. https://www.myjoyonline.com/news/nationwide-power-crisis-worsens/

56 Myjoyonline.com, "AGI to Lay Off Workers over Power Crisis," February 3, 2015, Accessed December 8, 2018.

https://www.myjoyonline.com/news/agi-to-lay-off-workers-over-power-crisis/.

57 Kojo, Emmanuel, “'Dumsor' Causes 13,000 Job Cuts in Four Months.” Apr 16, 2015b. Accessed September 23, 2020 ,

https://www.pulse.com.gh/news/dumsor-unemployment-dumsor-causes-13000-job-cuts-in-four-months/20xpn06.

58 Myjoyonline.com, “Dumsor Crisis: Over 12,000 Workers Lose Jobs in First Quarter," April 15, 2015, Accessed December 8, 2018. https://www.myjoyonline.com/business/dumsor-crisis-over-12000-workers-lose-jobs-in-first-quarter/\#!

59 GhanaWeb.com, "Government Needs \$4bn to Solve Energy Crisis," October 25, 2013, Accessed December 8, 2018,

https://www.ghanaweb.com/GhanaHomePage/business/Government-needs-4bn-to-solve-energy-crisis-289876.

60 Hasty, The Press and Political Culture, 18.

61 The \#bringbackourgirls trended when the 276 Chibok schoolgirls were kidnapped in 2014 in a school in Nigeria.
} 
or humorous information. ${ }^{62}$ Popular Ghanaian artists resisted and protested through songs compositions, comics and videos.

\section{Dumsor Activism}

As a focusing event, dumsor dumsorified state-citizen engagement. In April 2015, celebrities declared they had had enough and began gearing up to undertake a Dumsor Must Stop ${ }^{63}$ demonstration. The demonstration turned campaign, attracted wide public attention on social and mainstream media. In her work on service delivery protests in South Africa, von Schnitzler notes that such protests fundamentally draws attention to doubling of infrastructure exemplified in the slippage between "state fetishized goals" promises of service delivery and the actuality of unfulfilled promises. She further notes that, such protests shakes public imagination, defy traditional codes for civic engagement and challenge dominant forms of democratic practice. ${ }^{64}$ Dumsor activism fundamentally challenged the long held view of electricity governance as a delimited domain for "experts" and politicians and where communication and deliberation were channelled through citizen representatives in parliament and consumer advocates. Dumsor activism moved the conduct of politics from "normative locations" like party offices, parliament, campaign platforms and social media to the streets. ${ }^{65}$ Citizens decided to take their critique of government management and response of the crisis off social media to the streets.

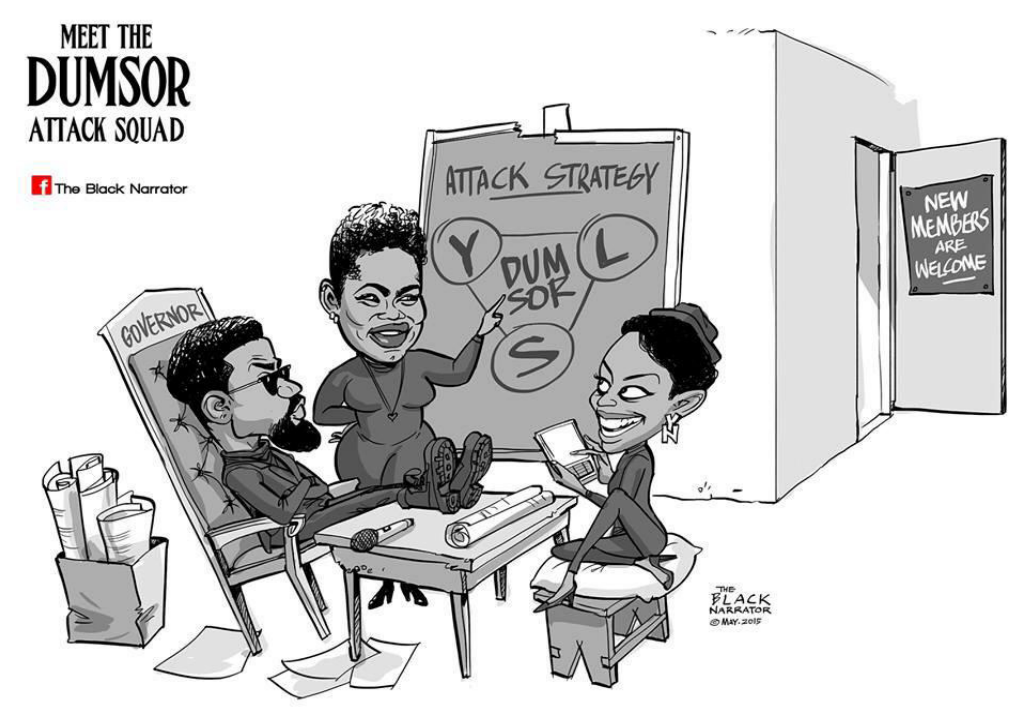

Fig 4: The Dumsor Attack Squad. Credit: The Black Narrator $2015^{66}$

On 16 May 2015 three celebrities Yvonne Nelson, Lydia Forson and Sarkodie (cartooned in Fig 4) led over 1500 Ghanaians clad in black and red colours holding placards, candles, lanterns rechargeable lamps and local kerosene tin lamps known as bobo and torch light in the Dumsor Must Stop vigil. ${ }^{67}$ Lanterns, torchlights and candles were used in pre-electric Accra. Protestors used these to symbolise their dumsorised "de-modernised" reality where they have now had to resort to using "old" tools like lanterns and candles for illumination them. One protestor stated:

Some of the stories (referring to dumsor stories) were funny. Most were sad and pitiful, a clear indication of the dire straits our nation finds itself in as a result of the government's incompetent and shambolic handling of the power crisis. This 'dumsor' crisis is crippling our nation and sapping the vitality out of the citizenry. It's a big shame that those we've given power to are failing to give us the power we need to keep our homes habitable, our factories producing and our businesses running. There is no sign yet that they will solve this problem anytime soon. ${ }^{68}$

Media accounts portrayed the protest as successful but the government represented by the Power Minister is reported to have downplayed the impact of the protest and apprehensions of protestors. Ghanaweb reported that the Minister said

"I want to walk into New York, go to a museum and see Ghanaian arts being exhibited" [...]According to him, the personalities involved in organizing the demonstration "don't have what it takes to make Ghana's cedi stable" and would want them to focus more on the crippling industry and make it a major foreign earner for the nation. As at

\footnotetext{
62 Tettey, Mobile Telephony and Democracy in Ghana, 16

${ }^{63}$ Emmanuel K Dogbevi, “Ghanaians Attend \#dumsormuststop Vigil to Protest Power Cuts,” May 16, 2015, Accessed March 22, 2020.

https:/www.ghanabusinessnews.com/2015/05/16/ghanaians-attenddumsormuststop-vigil-to-protest-power-cuts/

64 von Schnitzler, Democracy's Infrastructure, 3

65 von Schnitzler, Democracy's Infrastructure, 3

Killakam, Okayafrica's Top 15 Songs of 2015, Accessed March, 23, 2020, https://www.okayafrica.com/okayafrica-top-african-songs-2015/

67 Dogbevi, "Ghanaians Attend \#dumsormuststop Vigil to Protest Power Cuts", 2015

68 Ato-Kwamena Dadzie,“\#Dumsormuststop: A Vigil for Posterity,” MAY 17, 2015. Accessed September 9, 2020,

https://atokd.com/articles/dumsormuststop-a-vigil-for-posterity/
} 
now, the artistic industry isn't at an enviable level...I don't see why they are trying to turn an artistic group into a political action group." 69

The Minister's tone deaf characterisation of Dumsor Must Stop Vigil as held by incompetent celebrities rather than as "political acts" or "political spectacle"70 was a political tactic to dismiss and downplay the glaring rising citizen tension as acts of a few elite loud citizens. It was to render impalpable and delegitimise if any, citizen's perception of protest as an effective tool for political address in electricity governance. Observers warned that President Mahama's appointees and NDC members should prioritise restoring public trust over attacking people who criticised President Mahama and his management of the crisis or risk losing the 2016 elections: "if NDC believes that the solution to dumsor is by attacking anyone who criticises President Mahama [...] then they better think again because the insults [...] abuses is making the government unpopular and the party unattractive to the electorate."71

\section{Dumsor is Over, Dumsor is dead!}

In July 2015, ECG was forced to suspend the dumsor league table because the inconsistent levels of power generated made it impossible to schedule dumsor. ${ }^{72}$ The dumsorification of the manufacturing and industrial subsectors adversely impacted GDP growth. ${ }^{73}$ The health sector was also impacted. By September 2015 however, the PURC begun assuring citizens that dumsor will soon end. This was probably to cool tempers as the PURC was about finalising a major electricity tariff review. At this point, citizens banked all their hopes on the coming of the Karpower barges to avert dumsor. The Power Minister also issued his fair share of assurances but he also told consumers to manage their expectations. On 29 November 2015, the 225MW ship, Aysegul Sultan, docked and was greeted with pump and pageantry at the Tema Harbour. The much awaited saviour had arrived to relive the dumsorified Ghana off its dumsorforic effects. The second emergency plant, AMERI was also installed and had its test run in December 2015. In mid-December amidst a dumsorised atmosphere, the PURC increased electricity tariffs by almost 59.2 per cent. The cash trapped utilities sector welcomed the increases but the public condemned it.

In his 2016 State of the Nation Address, President Mahama lauded his government and the utilities sector for ending dumsor but emphasized that more needed to be done to consolidate the progress so as to avert a return to dumsor. The obituary (refer Figure 5) designed in a Ghanaian fashion reflects the deeply politicised characterisation of $d u m s o r$. The chief mourners it identifies are leading executives of the leading NPP party that vehemently criticised the President Mahama's management of dumsor. It identified dumsor as a propaganda pillar of the NPP and portrayed the NPP as enemies of progress.

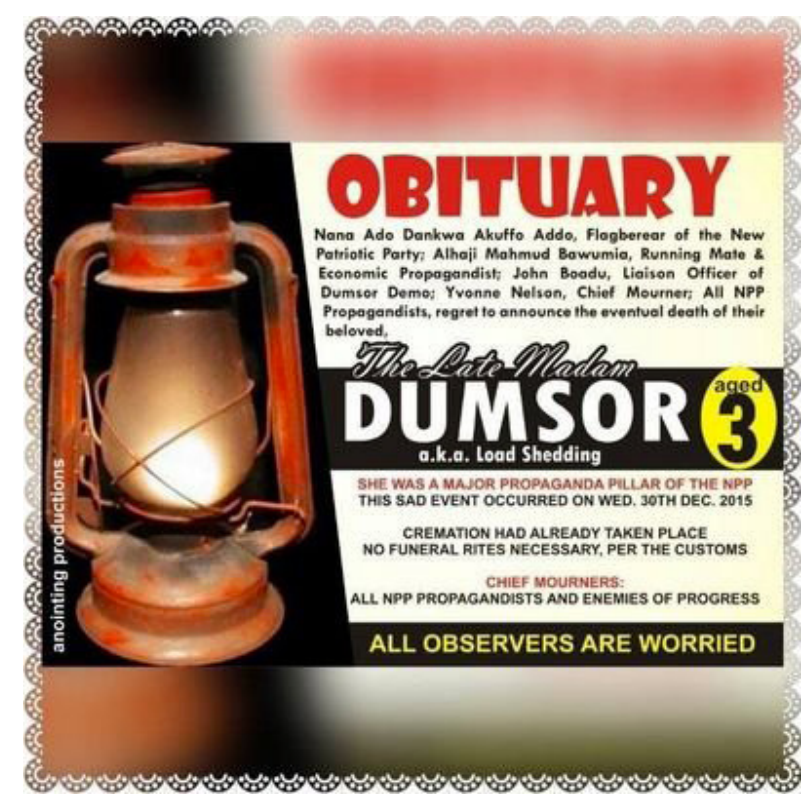

Fig 5: R.I.P Dumsor Credit: iam_richmann 2015

\footnotetext{
69 GhanaWeb, "Power Minister Lambasts \#DumsorMustStop Celebrities," May 12, 2015,

https://www.ghanaweb.com/GhanaHomePage/NewsArchive/Power-Minister-lambasts-DumsorMustStop-celebrities-357892

70 von Schnitzler, Democracy's Infrastructure, 2-4

71 Kofi Ata, “Can Mahama’s Appointees shut up over Dumsor Vigil?” Updated 16 May 2015,

https://www.modernghana.com/news/617842/can-mahamas-appointees-shut-up-over-dumsor-vigil.html

72 Daily Graphic, "ECG Says Load-Shedding Timetable Cannot Be Followed," Updated July 16, 2015,

https://www.peacefmonline.com/pages/local/news/201507/248042.php

73 GDP decreased to between 3.5-3.9 per cent from 4 per cent in 2014 and 7.9 per cent in 2012: Energy Commission 2016; Ghana Statistical Service 2013; 2015
} 
Later in April, President Mahama recanted and said dumsor wasn't over. Compared to 2015, the grid expanded by 19 per cent, 13 per cent more electricity was generated and peak load was roughly 14 percent more by the end of $2016 .{ }^{74}$ Despite state agencies declaring the end of dumsor, an average a maximum of 740MW load was shed because of fuel supply challenges: Akosombo was over drafted and gas supply was suspended between June to November because of Volta River Authority's (VRA) ${ }^{75}$ indebtedness to N-Gas and WAPCO. ${ }^{76}$ The factors that intensified dumsor, "non-dependable plant capacities, quantities of fuel and funds to purchase the fuel in a timely manner", still remained. ${ }^{77}$

During fieldwork interaction in September 2016, the Author gathered that dumsor was not over, it was only being masked. Government had purchased enough crude oil for VRA to generate enough fuel to get the country through elections and mislead voters into thinking that dumsor was over; dumsor was going to return in 2017 after the Presidential elections. Although the government declared it dead, the interlocutors still experienced dumsor: it was unpredictable but predominately, not lasting beyond 12 hours. Interlocutors were less apprehensive but were still in the "dumsor mode". President Mahama came out to assure Ghanaians and took responsibility for dumsor. He stated: "If you look at the energy sector, people keep talking about 'dumsor' but I will not blame anyone. I am the one who was voted as President of Ghana so I will confront it and fix it." again, he "promised Ghanaians that very soon, they will enter into an era of energy security." ${ }^{3}$

Across STS and anthropology, it has been argued that the technological style and system culture that a society adopts for its electricity systems shapes the user expectations and assumptions about what is normal and possible. ${ }^{79}$ Accra urbanites' imagination and conception of electricity supply and whose responsibility it was to provide such a service shaped their response to dumsor and who to direct their disenchantment about dumsor at. Government response to the crisis emerged in response to changing citizen expectations and demands. Although, blackouts are normal in Ghana, the prolonged and erratic nature of dumsor disrupted social practices and economic activity. These dire consequences informed citizens' response and anger which translated in the then President Mahama being held responsible for technical failures. As Abram, Winthereik and Yarrow point out, electricity today has become a visible political force in the lives of users and research must pay empirical attention into actor behavior in electricity systems.$^{80}$ The Ghanaian dumsor story sheds interesting learning points on actor behaviour, technological and political entanglements in crisis response and management. A seeming technical fault altered the political climate and decidedly ousted an incumbent regime in Ghana.

\section{CONCLUSION}

Through this historical overview, this article has established the direct relationality between state power and electric power. For instance, President Mahama promising to end dumsor, persistently failing to deliver this promise and yet continually trying to assure the public that he controls the grid and has authority to end dumsor. Although dumsor became a means for consumer advocates and the opposition to critic the competency of system builders, it created an avenue for politicians to express their authority through promises. By purporting to wield the power to banish dumsor, thus establishing he alone controls when consumers can have electricity, as the lights flickered on and off, state power became a visible force in the lives of consumers.

Dumsor reconfigured state-citizen relations in electricity governance: the effects of dumsor altered the modes of doing politics in the sector. The material agency of the grid exercised through its refusal to modulate practices shaped new forms of political agency in consumers. The citizens' novel technopolitical strategy to actively speak to power on their struggles with dumsor expanded the public sphere through the mass media. The citizen led dumsor activism contested statecraft of dumsor which effectively mounted pressure on system builders to introduce emergency measures. Here, grid oppressed consumers mobilized their voter currency (power) and emerged as powerful actants pressuring politicians to resolve the crisis. These political acts pressured government to contract so many IPPs. The result of which is now an installed capacity of 5,083 megawatts (MW), almost double the peak demand (2,700MW) and 60 percent

\footnotetext{
Energy Commission, "2016 Energy (Supply and Demand) Outlook for Ghana,"2016.

Volta River Authority is the state owned electricty generator

Volta River Authority, “55th Annual Report \& Accounts 2014." Volta River Authority, 2016,10.

Energy Commission, "2017 Energy (Supply and Demand) Outlook for Ghana," 2017, vii

President Mahama, "I won't blame anyone for Dumsor", Accessed March 23, 2020.

https://www.ghanaweb.com/GhanaHomePage/NewsArchive/I-won-t-blame-anyone-for-dumsor-I-ll-fix-it-Mahama-468780

79 Hannah Appel, Nikhil Anand, and Akhil Gupta, "Introduction: Temporality, Politics, and the Promise of Infrastructure," In The Promise of Infrastructure, eds by Nikhil Anand, Akhil Gupta and Hannah Appel, (Durham:Duke University Press, 2018) 1-38. Thomas Parke Hughes, Networks of Power: Electrification in Western Society, 1880-1930, (Baltimore: Johns Hopkins University Press, 1983); Thomas Parke Hughes, "Technology and Heterogeneous Engineering: The Case of Portuguese Expansion." In The Social Construction of Technological Systems: New Directions in the Sociology and History of Technology; [Papers of a Workshop Held at the University of Twente, the Netherlands, in July 1984], eds Wiebe E. Bijker, Thomas P. Hughes and Trevor Pinch. [Nachdr.], (Cambridge, Mass.: MIT Press, 1987), 111-34; Sarah Strauss, Stephanie Rupp, and Thomas F. Love, "Introduction. Powerlines: Cultures of Energy in the Twenty-First Century," In Cultures of Energy: Power, Practices, Technologies. eds Sarah Strauss, Stephanie Rupp and Thomas F. Love, (Walnut Creek, CA: Left Coast Press, 2013), 10-41; von Schnitzler, Citizenship Prepaid, (2008)

80 Simone Abram, Brit Ross Winthereik, and Thomas Yarrow, “Current Thinking - an Introduction," In Electrifying Anthropology, eds Simone Abram, Brit R.
} Winthereik and Thomas Yarrow, (London: Bloomsbury Academic, 2019), 1-21. 
excess capacity from take-and-pay contracts, costing taxpayers US $\$ 520$ million. From 2020, Ghana was projected to face annual excess gas capacity charges of between US $\$ 550$ and US $\$ 850$ million. ${ }^{81}$ President Mahama's government signed contracts anticipating economic growth, increased demand and all contracted IPPs not reaching financial closure. State efforts to control dumsor have now saddled the taxpayer with monetary burden.

Finally, Infrastructure breakdown technopolitics differ from infrastructure design and life cycle technopolitics in two ways. First, breakdown technopolitics are often ad hoc symbolic political acts to compensate for technological failures. Seen in President Mahama's setting up a Ministry, appointing a Minister and setting up committees to end dumsor when it was evident that funds to procure fuel and additional generation infrastructure was what the sector required. Secondly, electoral cycles are critical determinants in the choice of technopolitical strategy as politicians tend to time interventions to coincide with voting periods. With dumsor, politicians timed emergency power and stocking fuel to coincide with campaign periods to influence voter decisions. This technopolitical strategy worked in 2012 but failed in 2016.

\section{ABOUT AUTHOR}

Claudia Serwah Prempeh is a Junior Fellow, Bayreuth International Graduate School of African Studies (BIGSAS), University of Bayreuth, Germany.

\section{FUNDING}

This work was supported by the Bayreuth International Graduate School of African Studies (BIGSAS), University of Bayreuth, Germany.

\section{BIBLIOGRAPHY}

Abebrese,Ama K (@Ama_K_Abebrese). “The Dumsorification of \#Ghana Has Had a Dumsorforic Effect on the Country. We Now Await Dumsorly for the End of \#Dumsor,"Twitter, November 25, 2015, https://twitter.com/Ama_K_Abebrese/status/669521731028164608

Abram, Simone, Brit Ross Winthereik, and Thomas Yarrow. "Current Thinking - an Introduction." In Electrifying Anthropology, edited by Simone Abram, Brit R. Winthereik and Thomas Yarrow, 1-21. London: Bloomsbury Academic, 2019.

Ackah, Charles. "Electricity Insecurity and Its Impact on Micro and Small Businesses. Report Presentation Given to Economy of Ghana Network of the Institute of Statistical, Social, and Economic Research, May 14, 2015." https://isser.ug.edu.gh/sites/isser.ug.edu.gh/files/ISSER_ANNUAL_REPORT 2014-2015.pdf

Acquah, Raymond. “\$2.2 Million Lost Daily to 'Dumsor' - ISSER.” Updated May 14, 2015”. http://citifmonline.com/2015/05/2-2-million-lost-daily-to-dumsor-isser/

AFAG. "Another Utility Increase; Unbearable Hardship-Time to Strike." October, 2014. News release. Accessed September 1 2020. https://www.peacefmonline.com/pages/politics/politics/201410/217163.php

Agyeman, Nana Sarpong (@IngSarpong). “Dumsor Is Village Explanation of Power Crisis \& Load Shedding Is the Engineering Cocastic Explanation to Dazzle the Village Folks," Twitter November 19, 2015, 8:33am https://twitter.com/IngSarpong/status/667244368177332224

Anand, Nikhil. "Pressure: The Politechnics of Water Supply in Mumbai." Cultural Anthropology 26, no. 4 (2011): 542-64. https://doi.org/10.1111/j.1548-1360.2011.01111.x

. "Municipal Disconnect: On Abject Water and Its Urban Infrastructures." Ethnography 13, no. 4 (2012): 487-509. https://doi.org/10.1177/1466138111435743 ."Leaky States: Water Audits, Ignorance, and the Politics of Infrastructure." Public Culture 27, 276 (2015): 305-30. https://doi.org/10.1215/08992363-2841880

Appel, Hannah, Nikhil Anand, and Akhil Gupta. "Introduction: Temporality, Politics, and the Promise of Infrastructure." In The Promise of Infrastructure, edited by Nikhil Anand, Akhil Gupta and Hannah Appel, 1-38. Durham: Duke University Press, 2018.

Ata, Kofi. “Can Mahama’s Appointees shut up over Dumsor Vigil?” Updated 16 May 2015. Accessed September 32020. https://www.modernghana.com/news/617842/can-mahamas-appointees-shut-up-over-dumsor-vigil.html

Birkland, Thomas A. After Disaster: Agenda Setting, Public Policy, and Focusing Events. American governance and public policy. Washington, DC: Georgetown University Press, 1997.

Bowker, Geoffrey C., and Star Susan Leigh. Sorting Things Out: Classification and Its Consequences. Inside technology. Cambridge, Mass., London: MIT Press, 1999.

\footnotetext{
$\overline{81}$ Ministry for Finance and Economic Planning, “The 2019 Mid-Year Fiscal Policy Review \& Supplementary Estimates.” Accra, 2019
} 
Carlisle, Juliet E., Feezell, Jessica T., Michaud E. H. Kristy, and Smith Eric R. A. N. The Politics of Energy Crises. New York, NY: Oxford University Press, 2017.

Casely-Hayford, Sydney. "Ntro Twa-Preneur." Updated July 7, 2015. https:/www.peacefmonline.com/pages/comment/features/201512/264170.php

Dadzie, Ato-Kwamena. “\#Dumsormuststop: A Vigil for Posterity." May 17, 2015. Accessed September 9, 2020. https://atokd.com/articles/dumsormuststop-a-vigil-for-posterity/

Daily Graphic. "ECG Says Load-Shedding Timetable Cannot Be Followed.” Updated July 16, 2015. Accessed September 10 2020. https://www.peacefmonline.com/pages/local/news/201507/248042.php

Di Nunzio, Marco. “Anthropology of Infrastructure." Governing Infrastructure Interfaces Research Note, no.01 (2018).

Dogbevi, Emmanuel K. "Ghanaians Attend \#dumsormuststop Vigil to Protest Power Cuts." May 16, 2015. Accessed September 23, 2020. https://www.ghanabusinessnews.com/2015/05/16/ghanaians-attenddumsormuststop-vigil-to-protest-power-cuts/

Dogbey, Alfred K. “End of 'Dum so Dumso': Mahama Sleeping Comfortably Now." August 5, 2013. Accessed March 25, 2020. https://www.ghanaweb.com/GhanaHomePage/NewsArchive/End-of-Dum-so-Dumso-Mahamasleeping-comfortably-now-281485

Donkor, Kwabena. “FULL SPEECH: Govt Regrets 'Dumsor' - Dr Donkor.” Feb 3, 2015. Accessed July 7, 2015. https:// www.graphic.com.gh/news/general-news/full-speech-govt-regrets-dumsor-dr-donkor.html

Edwards, Paul N., and Hecht Gabrielle. "History and the Technopolitics of Identity: The Case of Apartheid South Africa." Journal of Southern African Studies 36, no. 3 (2010): 619-39. https://doi.org/10.1080/03057070.2010.507568

Energy Commission. "2010 Energy (Supply and Demand) Outlook for Ghana." Energy Commission, Accra, 2010. . "2012 Energy (Supply and Demand) Outlook for Ghana." Energy Commission, Accra, 2012. .2015 Energy (Supply and Demand) Outlook for Ghana." Energy Commission, Accra, 2015. .2016 Energy (Supply and Demand) Outlook for Ghana." Energy Commission, Accra, 2016. ."2017 Energy (Supply and Demand) Outlook for Ghana." Energy Commission, Accra, 2017.

Flagstaff House Communications Bureau. "Mahama Tasks New Power Minister to End 'Dumsor' Quickly." December 20, 2014. Accessed September 23, 2020. https://www.ghanaweb.com/GhanaHomePage/NewsArchive/Mahamatasks-new-Power-Minister-to-end-dumsor-quickly-339869

Gadugah, Nathan. “Ghana’s Power Crisis; a Slippery Slope to Eternal Darkness.” December 11, 2014. Accessed July 8, 2015. https://www.todaygh.com/ghanas-power-crisis-slippery-slope-eternal-darkness/

Ghana Statistical Service. "Revised 2012 Annual Gross Domestic Product." Ghana Statistical Service, Accra, 2013. ."Revised 2014 Annual Gross Domestic Product." Ghana Statistical Service, Accra, 2015.

Ghanaweb. "Government Needs \$4bn to Solve Energy Crisis." October 25, 2013. Accessed December 8, 2018. https://www.ghanaweb.com/GhanaHomePage/business/Government-needs-4bn-to-solve-energycrisis-289876

. "Power Minister Lambasts \#DumsorMustStop Celebrities." May 12, 2015. https://www.ghanaweb.com/ GhanaHomePage/NewsArchive/Power-Minister-lambasts-DumsorMustStop-celebrities-357892

. "I won't blame anyone for Dumsor", Accessed March 23, 2020.

https://www.ghanaweb.com/GhanaHomePage/NewsArchive/I-won-t-blame-anyone-for-dumsor-I-ll-fix-itMahama-468780

Graham, Stephen. "When Infrastructures Fail." In Disrupted Cities: When Infrastructure Fails. Edited by Stephen Graham. 1st ed., 1-26. New York, NY: Routledge, 2010.

Graham, Stephen, and Marvin Simon. Splintering Urbanism: Networked Infrastructures, Technological Mobilities and the Urban Condition. London, New York: Routledge, 2001.

Graham, Stephen, and Thrift Nigel. “Out of Order." Theory, Culture \& Society 24, no. 3 (2007): 1-25. https://doi.org/10.1177/0263276407075954

Harvey, Penelope, Jensen Casper Bruun, and Morita Atsuro. "Introduction: Infrastructural Complications." In Infrastructures and Social Complexity: A Companion. Edited by Penelope Harvey, Casper B. Jensen and Atsurō Morita, 1-22. Culture, Economy and the Social. London, New York: Routledge, Taylor \& Francis Group, 2017.

Harvey, Penny, and Knox Hannah. “The Enchantments of Infrastructure.” Mobilities 7, no. 4 (2012): 521-36. https://doi.org/10.1080/17450101.2012.718935

Hasty, Jennifer. The Press and Political Culture in Ghana. Bloomington: Indiana University Press, 2005.

Hecht, Gabrielle. The Radiance of France: Nuclear Power and National Identity after World War II. Inside technology. Cambridge, Mass., London: The MIT Press, 1998.

. "Technology, Politics, and National Identity in France." In Technologies of Power: Essays in Honor of Thomas Parke Hughes and Agatha Chipley Hughes. Edited by Michael T. Allen and Gabrielle Hecht, 253-94. Cambridge, Mass.: MIT Press, 2001. 
.Introduction." In The Radiance of France: Nuclear Power and National Identity after World War II. Edited by Gabrielle Hecht, 1-20. Inside technology. Cambridge Mass: MIT Press, 2009.

Hughes, Thomas Parke. Networks of Power: Electrification in Western Society, 1880-1930. Baltimore: Johns Hopkins University Press, 1983.

. "Technology and Heterogeneous Engineering: The Case of Portuguese Expansion." In The Social Construction of Technological Systems: New Directions in the Sociology and History of Technology; [Papers of a Workshop Held at the University of Twente, the Netherlands, in July 1984]. Edited by Wiebe E. Bijker, Thomas P. Hughes and Trevor Pinch. [Nachdr.], 111-34. Cambridge, Mass.: MIT Press, 1987.

Kojo, Emmanuel. “ECG Releases 'Dumsor' League Table.” February 6, 2015b. Accessed September 23, 2020. https://www.pulse.com.gh/news/energy-crisis-ecg-releases-dumsor-league-table/b4w7g32

."Dumsor' Causes 13,000 Job Cuts in Four Months." Apr 16, 2015a. Accessed September 23, 2020. https://www. pulse.com.gh/news/dumsor-unemployment-dumsor-causes-13000-job-cuts-in-four-months/20xpn06

Parliament of Ghana."State of the Nation Address Presented to Parliament By HE John Dramani Mahama President of the Republic Of Ghana, 2016" February 25, 2016. Accessed September 23, 2020.

http://ir.parliament.gh/handle/123456789/611

Ministry for Finance and Economic Planning. “The 2019 Mid-Year Fiscal Policy Review \& Supplementary Estimates.” Accra, 2019.

Ministry of Energy. "National Energy Policy." 2010. http://www.purc.com.gh/purc/sites/default/files/ENERGYPOLICY.pdf

Mitchell, Timothy. Rule of Experts: Egypt, Techno-Politics, Modernity. Berkeley, Calif., London: University of California Press, 2002.

."Carbon Democracy." Economy and Society 38, no. 3 (2009): 399-432. https://doi.org/10.1080/03085140903020598

Myjoyonline.com. "Nationwide Power Crisis Worsens." Accessed June 4, 2016. https://www.myjoyonline.com/news/nationwide-power-crisis-worsens/ . "AGI to Lay off Workers over Power Crisis." February 3, 2015. Accessed December 8, 2018. https://www.myjoyonline.com/news/agi-to-lay-off-workers-over-power-crisis/ ."Dumsor Crisis: Over 12,000 Workers Lose Jobs in First Quarter." April 15, 2015. Accessed December 8, 2018. https://www.myjoyonline.com/business/dumsor-crisis-over-12000-workers-lose-jobs-in-first-quarter/\#!

Nene, O. Nene (@NeneMAGORTEY). “Chronology of Mahama’s Promises to End Dumsor,” Twitter May16, 2015. https://twitter.com/NeneMAGORTEY/status/599618716096143360

Nye, David E. Consuming Power: A Social History of American Energies. Cambridge Mass: MIT Press, 1998.

Obour, Samuel K. "My Banish Dumsor" Comment Was Only a Prayer Request - President Mahama." January 7, 2015. Accessed September 23, 2020. https://www.graphic.com.gh/news/politics/my-banish-dumsor-comment-wasonly-a-prayer-request-president-mahama.html

Osam, Efua Idan. “I Will 'Banish Dumsor Forever' - Mahama.” July 7, 2015a. Accessed September 23, 2020. http://citifmonline.com/2015/01/will-banish-dumsor-forever-mahama/

Osam, Efua Idan. “Stop Embarrassing Yourself - Cudjoe to Power Minister." May 9, 2015b. Accessed March 23, 2020. http://citifmonline.com/2015/05/stop-embarrassing-yourself-cudjoe-to-power-minister/

Owusu, William Yaw. "Mahama Pledges Not to Make Promises to Ghanaians Again." December 3, 2014. Accessed March 5, 2020. https://newsghana.com.gh/mahama-pledges-not-to-make-promises-to-ghanaians-again/

Peacefmonline. "Dumsor Will Be Like the Egyptians; We Shall See Them No More Minister." February 5, 2015. Accessed March 17, 2020. https://www.peacefmonline.com/pages/local/news/201502/231358.php

Quashie, S. "This Timeline Dates Far Back as 2012 and Ends with the Latest Comment on the Power Crisis by John Mahama." May 5, 2015. Accessed July 4, 2015. https://www.pulse.com.gh/news/dumsormuststop-a-timeline-ofgovernment-promises-and-lies-from-2012/fzzyqzm

Rudnyckyj, Daromir. "Crisis Effects.” Cultural Anthropology 33, no. 4 (2018): 547-57. https://doi.org/10.14506/ca33.4.04 Rupp, Stephanie. "Considering Energy E = Mc2 = (Magic Culture)2." In Cultures of Energy: Power, Practices, Technologies. Edited by Sarah Strauss, Stephanie Rupp and Thomas F. Love, 79-98. Walnut Creek, CA: Left Coast Press, 2013.

Selormey, Ernestina Edem. "Citizen Voice and Bureaucratic Responsiveness FM Radio Phone-Ins and the Delivery of Municipal and Local Government Services in Accra, Ghana." Doctor of Philosophy, University Of Sussex, 2013.

Sey, Araba. "New Media Practices in Ghana." International Journal of Communication 5 (2011).

Smith, Merritt Roe. “Technological Determinism in American Culture?” In Does Technology Drive History? The Dilemma of Technological Determinism. Edited by Merritt R. Smith and Leo Marx, 3-34. Cambridge, Mass: MIT Press, 1994. 
Strauss, Sarah, Rupp Stephanie, and Love Thomas F.. "Introduction. Powerlines: Cultures of Energy in the TwentyFirst Century." In Cultures of Energy: Power, Practices, Technologies. Edited by Sarah Strauss, Stephanie Rupp and Thomas F. Love, 10-41. Walnut Creek, CA: Left Coast Press, 2013.

Tettey, Wisdom J. "Mobile Telephony and Democracy in Ghana: Interrogating the Changing Ecology of Citizen Engagement and Political Communication." Telecommunications Policy 41, 7-8 (2017): 685-94. https://doi.org/10.1016/j.telpol.2017.05.012

Volta River Authority. "Fifty Third Annual Report \& Accounts 2014." Volta River Authority, 2014. . "55th Annual Report \& Accounts 2016." Volta River Authority, 2016.

von Schnitzler, Antina. "Citizenship Prepaid: Water, Calculability, and Techno-Politics in South Africa*." Journal of Southern African Studies 34, no. 4 (2008): 899-917. https://doi.org/10.1080/03057070802456821 . "Traveling Technologies: Infrastructure, Ethical Regimes, and the Materiality of Politics in South Africa." Cultural Anthropology 28, no. 4 (2013): 670-93. https://doi.org/10.1111/cuan.12032 .Democracy's Infrastructure: Techno-Politics and Protest after Apartheid. Princeton Studies in Culture and Technology. Princeton: Princeton University Press, 2016.

White, Leslie A. "Energy and the Evolution of Culture." American Anthropologist, New Series 45, no. 3 (1943): 335-56. Winner, Langdon. “Do Artifacts Have Politics?” Daedalus 109, no. 1 (1980): 121-36. http://www.jstor.org/stable/20024652 